\title{
Exploring the key behavioural, functional and strategic competencies in Indian management education
}

\author{
Nidhi Shukla ${ }^{*}$, S K Prasad ${ }^{2}$, Urmila Itam ${ }^{3 *}$ \\ School of Management Studies, REVA University, Bangalore, Karnataka, India ${ }^{1}$ \\ School of Management Studies, REVA University, Bangalore, Karnataka, India ${ }^{2,3}$ \\ nidhis05@gmail.com ${ }^{1 *}$, drskprasad09@gmail.com ${ }^{2}$, urmila.itam@reva.edu.in $^{3 *}$
}

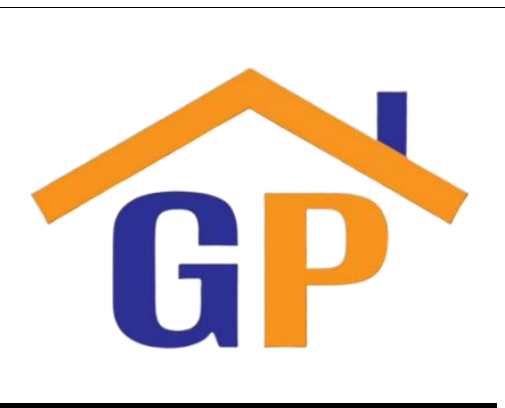

Article History

Received on 11 February 2021

$1^{\text {st }}$ Revision on 14 March 2021

$2^{\text {nd }}$ Revision on 26 March 2021

Accepted on 31 March 2021

\begin{abstract}
Purpose: The study's primary purpose is to identify the critical sustainable competencies and their importance in Indian management education perceived by the stakeholders.

Research Methodology: The study adopted an explanatory research design and a standardised questionnaire to gather data from stakeholder groups.
\end{abstract}

Results: The results suggest that the competency clusters considered necessary by the main stakeholder groups are behavioural, functional and strategic.

Limitations: Broader perspective with more samples at various locations will add more value to the idea.

Contribution: This paper aims to support both business and academia by recommending a positive collaborative process and building a workforce ready for work.

Keywords: Sustainability, Competencies, Management education, Stakeholders, Job markets

How to cite: Shukla, N., Prasad, S. K., \& Itam, U. (2021). Exploring the key behavioural, functional and strategic competencies in Indian management education. International Journal of Financial, Accounting, and Management. 3(1), 65-82.

\section{Introduction}

MBA (Master of Business Administration) program is the most sought-after course for formal education in management. Graduates of MBA programs are expected to be 'corporate ready', but in reality, the gap exists. This 'employability skills gap' is one of the prime challenges facing the industry and academia today. India Skills Report 2020 found that only $46 \%$ of students to be corporate ready. However, the employability percentage of MBA graduates in the last five years has been quite dismal $(2015-43.99 \%, 2016-44.56 \%, 2017-42.28 \%, 2018-39.4 \%, 2019-36.44 \%$ and 2020-54\%). While the demand for MBA Graduates increased from $13 \%$ in 2019 to $17 \%$ in 2020 , stakeholders of management education - employers, educators and students intuitively know that there is an issue with the entire model; however, they are not sure where the problem lies (Thomas, Thomas \& Wilson, 2013).

Mentoring, informal training and job experience are the main ways learning occurs (Pfeffer \& Sutton, 2000). However, these methods (McCauley, Moxley, \& Van Velsor, 1998) are relatively inefficient and unsystematic. It would, therefore, be valuable from an industry point of view to impart the most desired skills during the study. The top outcome of Management Education is the quality-driven employability developed during the program (Kooli C, 2019; 2020; Wille, De Fruyt, \& Feys, 2013). Consequently, employability has emerged as a topic of interest and research in professional programs (Akkermans \& Kubasch, 2017). According to Kooli C (2019), quality is the biggest constraint and many higher education institutions operate major academic activities without a clear strategic direction. This has resulted in increased attention and expectation from the industry towards 
employability competencies developed during the course. The industry sees employees as their competitive advantage, given that the employees' outputs and ability increase the effectiveness and overall performance outcomes of an organisation (Al-Abri, N., \& Kooli, C. 2018; Buller \& McEvoy, 2012; Deaconu et al., 2014). This study explores and suggests a competency-based approach to meet the industry expectation of MBA graduates' sustainable employability.

\section{Objectives of the study}

1. To identify the most important competencies perceived by the key stakeholder groups of management education - MBA Educators, MBA Alumni, MBA Students and Recruiters.

2. To test the difference in the perception of the four key stakeholder groups of management education considered in this study.

3. To suggest the 'Key Competencies' to the academia that can meet industry expectations of sustainably employable business management graduates.

\section{The theoretical background of the study}

Management Education in India is primarily a derivative of western management practices and thoughts. The youngsters consider it an attractive option because of its wide acceptance in the job market and pay structures. According to Wikipedia, management education in India has more than ten decades of history; however, India's first management program was started in 1948 by the Indian Institute of Social Sciences. In 1949, the Catholic community founded XLRI. Later Indian Institute of Social Welfare and Business Management (IISWBM - Kolkata 1953), FMS-Delhi (1954), IIM's (1960's) and many more business schools with a focus on professionalising the Indian management through teaching, research, training, consultation and institutional Business schools (Gupta, Gollakota, \& Sreekumar, 2003). Management education in India witnessed unprecedented growth between 1990 and 2010 due to privatisation and globalisation.

\subsection{Quality as a concern}

Management education in India is passing through a critical phase where issues related to quality, objectivity, and industry needs have to be addressed. A constant increase in the number of institutions being closed and the admission and placement ratio, which is recorded at 4:1, as per the database of the apex regulator for technical education in India - All India Council for Technical Education (AICTE) Table 1 emphasises the need to relook and align the outcome of management education programs.

Even the best in India is not the best internationally. The IIMs, particularly Ahmedabad, Calcutta, Bangalore, Lucknow, fail to appear in the top global $100 \mathrm{~B}$ - Schools in Business week ranking surveys, Financial times \& Forbs. Recent Bloomberg News states India will have the demographic advantage of having the world's largest workforce by 2027, with a billion people aged between 15 to 64 years. To reap the benefits, the education institutes should adopt an integrative-disciplinary approach making them corporate ready for the 'hybrid jobs' that have a prerequisite of sound technical skills, analytical skills and soft skills- Indian Education 4.0 (Deloitte Deans' Summit 2019).

Table 1. Yearly trends of business schools in India (Offering post-graduation in management)

\begin{tabular}{|c|c|c|c|c|c|c|c|}
\hline Year & $\begin{array}{c}\text { Total } \\
\text { Institutions }\end{array}$ & $\begin{array}{c}\text { New } \\
\text { Institutions }\end{array}$ & $\begin{array}{c}\text { Closed } \\
\text { Institutions }\end{array}$ & $\begin{array}{c}\text { Total } \\
\text { Intake }\end{array}$ & Faculties & Placement & Placement \% \\
\hline $2012-13$ & $\mathbf{3 8 6 5}$ & $\mathbf{9 7}$ & $\mathbf{4 2}$ & $\mathbf{4 4 3 2 8 2}$ & $\mathbf{3 8 7 3 7}$ & $\mathbf{9 5 1 9 1}$ & $\mathbf{2 1 . 4 7}$ \\
\hline $2013-14$ & 3740 & 19 & 62 & 450866 & 49757 & 103178 & $\mathbf{2 2 . 8 8}$ \\
\hline $2014-15$ & 3587 & 45 & 42 & 455097 & 57477 & 104431 & $\mathbf{2 2 . 9 5}$ \\
\hline $2015-16$ & 3450 & 23 & 65 & 431578 & 55434 & 101776 & $\mathbf{2 3 . 5 8}$ \\
\hline $2016-17$ & 3334 & 39 & 79 & 411826 & 53888 & 106022 & $\mathbf{2 5 . 7 4}$ \\
\hline $2017-18$ & 3233 & 47 & 35 & 393043 & 53605 & 98327 & $\mathbf{2 5 . 0 2}$ \\
\hline $2018-19$ & 3085 & 86 & 24 & 372579 & 43555 & 107519 & $\mathbf{2 8 . 8 6}$ \\
\hline
\end{tabular}

Source https://facilities.aicte-india.org/dashboard/pages/dashboardaicte.php 


\subsection{Concept of competencies}

McClelland (1973) first introduced the concept of competencies and stated it as a "critical differentiator of performance". Another competency was redefined by Boyatzis (1982) - "broadly as an underlying characteristic that could be a motive, trait, skill, an aspect of their self-image or social role, or body of knowledge which they use". Spencer and Spencer (1993) have recognised the significance of competency building in management education; thereby, the concept of competency progressed as theory and was recognised by governing bodies. Competency aims at higher job performance (Fleming et al., 2009; Le Deist and Winterton, 2005; McLagan, 1997). Competencies can also indicate a person's knowledge, capability, and objective (Ryan et al., 2009). According to Boyatzis (1982, 2008), maximum performance, stimulation and commitment are equivalent to the area of maximum overlap or integration between individual, job demands and organisational environment (pp. 753).

Literature suggests that competencies are classified into various categories. Input-based competency, transformational competency and output-based competency are the three classifications given by Lado and Wilson (1994). Hamel and Heene (1994) classified competencies based on their impact on the organisation: market access competency, integrity-related competency, and related functional competency (Hamel \& Prahalad 1994). Competencies are also classified by their nature - strategic capabilities, functional capabilities, organisational and adaptive capabilities (Malerba \& Marengo, 1995). Cognitive, emotional intelligence and social intelligence are the three behavioural clusters of competencies that differentiate outstanding from average performers (Boyatzis 2008).

Career competencies are positively related to the perceived employability of the individual. At the same time, success in a career results from the relationship between career competencies and perceived employability (Al-Abri, N., \& Kooli, C. 2018). Providing employment opportunity is one of the essential outcomes of the MBA program (Macatangay, 2013). Baruch, Bell \& Gray (2005) also observed that value addition and providing competencies for leadership and managerial roles are the primary goals of an MBA program. During the early years of the career, one should put substantial efforts to build up and maintain employability (Bridgstock, 2009). This translates into immediate and upcoming opportunities in the work sphere (Rothwell \& Arnold, 2007).

\subsection{Need and importance of competencies in Indian management education}

The largest and fastest-growing demographic group in India, i.e. millennial and Generation $\mathrm{Z}$ (Dutt 2018), will increase the number of job seekers by $27 \%$ between 2019-2020 (Wheebox). It is being found that the industry has never been satisfied with the available pool of talents produced by academic institutions. The current study identified some noticeable works and considered those works as a foundation for the current study to strengthen the argument.

Skill Gap Survey (2010) recorded a gap in attitude, knowledge and skills in the performance and expectations from fresh MBA Graduates hired in the Indian banking, financial services and insurance sector. Chronicles of Higher Education (2013) survey of 704 employers across the industry states that half of them admitted that they had trouble filling the vacancies due to candidates lacking in communication, adaptability, decision-making, and problem-solving capabilities. Deloitte Deans' Summit (2019) survey revealed that $97 \%$ of employees believe a constant need for upskilling and reskilling of the existing students and academics and industry tag the students to be 'moderately ready' to meet the expectation of the industry.

Deloitte's Global Millennial Survey (2019) highlighted $20 \%$ of millennial and Generation Z feel they have desired knowledge and skill to fit in the upcoming job openings. Louisville (2019) surveyed 600 HR leaders and observed that $64 \%$ of the employers admitted to the skill gap in their companies; $44 \%$ of employers stated that it was hard to fill the vacancies. Lack of skilled talent (31\% respondents) and non-availability of qualified candidates (30\% respondents) are reasons for widening the skill gap. India Skills Report 2020 highlights that $57 \%$ of the respondents across all sectors feel that very few job seekers meet the expected skill requirements to work in competitive businesses. Nobel Prizewinning economist James Heckman observed that the global economy's success would depend on the 
technical skills and the broader set of employability skills acquired by the workforce (Kautz et al.2020). Several studies stressed the need and importance of skills like critical thinking, leadership and creativity more than ever with the current advances in automation, cognitive computing and A.I. (Al-Abri, N., \& Kooli, C. 2019; Kooli, C 2020; Radin et al. 2020). Some companies like Google has researched and developed a checklist of the key skills possessed by its most effective managers and evolved their hiring strategy around the identified key skills (Harrell 2018). Looking into the current scenarios, the researchers have attempted to propose a model that integrates the industry requirement in curriculum building.

\section{Conceptual framework and hypotheses development}

The paradigm shift from the traditional competency approach to a strategic competency approach in organisations has confused researchers and practitioners. To have more clarity, the current study would like to identify the most used and requested competencies from all management education stakeholders. The study explores the behavioural competencies - emotional, social and cognitive intelligence elements of an individual (Boyatzis et al., 2008, 2009). According to ESCI reports, Self-awareness and selfmanagement clusters measure individual emotional competencies, social awareness and relationship management measure individual social competencies, systems thinking and pattern recognition measure individual cognitive competencies (Wolff, 2008). (Akimova 2000; Droge 1994; Hitt and Ireland 1985; Li 2000) confirmed that functional elements of the jobs can become the core competencies required for an organisation. Functional competencies are the set of specific skills, knowledge and attitudinal areas required for broad job function. Teamwork, oral communication, customer focus, initiative, professionalism and cultural sensitivity are considered as measurable functional competencies $\underline{(\mathrm{Li}, 2000}$; Nguyen, 2008). Strategically competent business designs have inspiring vision and purpose, flexible structure, self-organising teams, dynamic capabilities and implementable business models (Malerba and Marengo 1995). Leadership and management, innovation and business design are the three clusters identified under strategic organisation member capabilities (Anderson and Slade 2016; Collins 2001; Goldman and Scott, 2015).

The study identified a theoretical list of essential competencies from the following literature review and competency models- Harvard University Competency Dictionary (2008): captured employers perspectives of most critical competencies required in a particular job for performance management and developmental purposes, Anthony et al. (1990) in Workplace Basics: The Essential Skills Employers Want. ASTD Best Practices Series: Training for a Changing Work Force, discussed indepth about 16 skills referred to as workplace basics, as perceived by the employer, Model Curriculum for Management Program (MBA \& PGDM) - AICTE (All India Council of Technical Education - India) (2018): focused on six most essential learning outcomes of the management program and AACSB(1987) Managerial Competencies by AMA/McBer and Company as also confirmed by Boyatzis(1982) in The Competent Manager and American Assembly for Collegiate Schools of Business-AACSB(1987), had a common approach towards developing competency-based business/management education, training and development.

Based on the above discussions and the synthesis of the existing academic and consultant works, the current study proposed a conceptual framework as shown in figure 1, where main components include the three clusters of competencies covering behavioural, functional and strategic competencies and the stakeholders' perceptions, which include educators, MBA Alumni, MBA Students, and Recruiters. This model reports the importance of integrative perspective by including all the stakeholders' perceptions of competency building. To address the consensus of item allocation to each competency cluster, factor analysis with the principle component method will determine the underlying factors. Later one way ANOVA will analyse the perceptions of stakeholders towards competency clusters. 


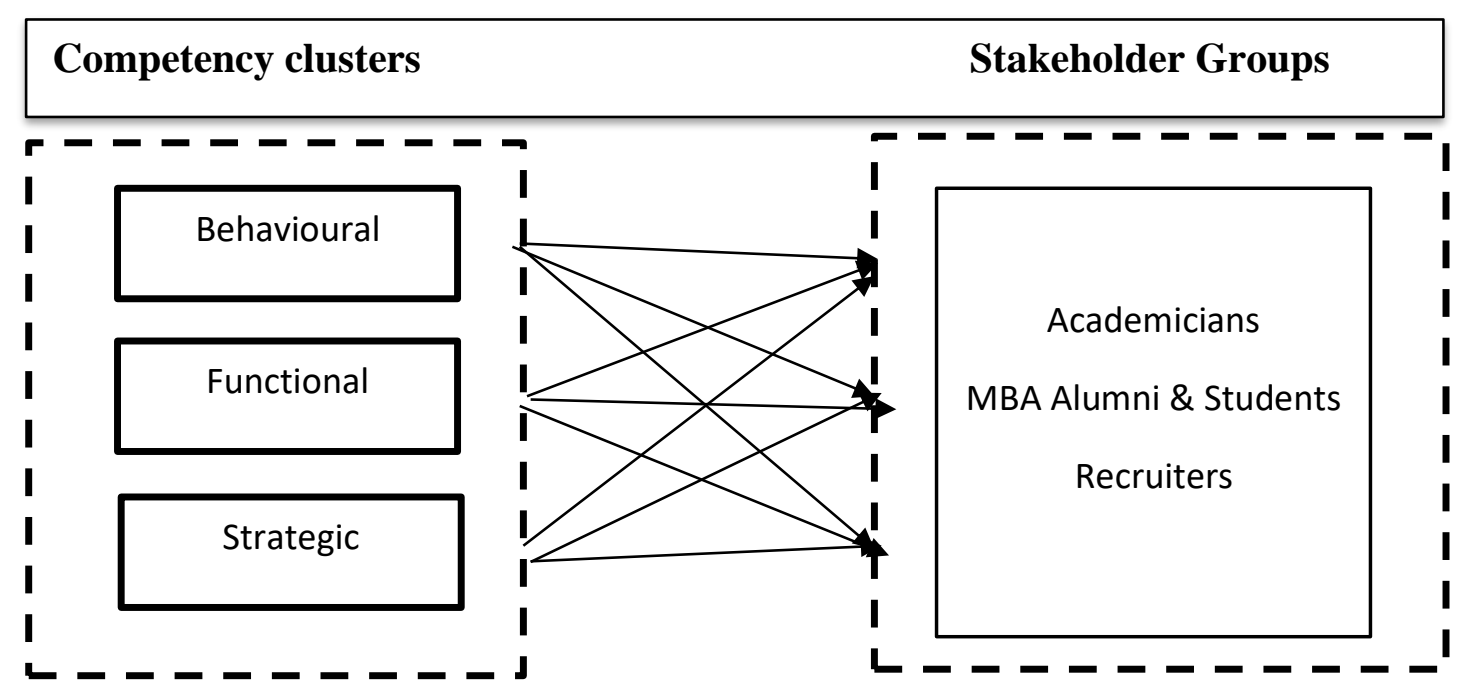

Figure 1. Conceptual model

The hypotheses to be tested in the study are framed based on the research questions, objectives and conceptual framework developed from the literature review. All three hypotheses claim a significant difference between the perceptions of each stakeholder groups towards identified competency clusters. The developed hypotheses were strongly supported by several studies both theoretically and empirically (Boyatzis et al., 2008, 2009; Deloitte Deans' Summit 2019; Goldman and Scott, 2015; Li, 2000; Louisville 2019; Nguyen, 2008; Wolff, 2008; Zhao, 2018)

The study puts to test the following research hypothesis:

Research Hypothesis - H1: There is a significant difference between each key stakeholder group's perceptions of behavioural competencies.

Research Hypothesis - H2: There is a significant difference between each key stakeholder group's perceptions of functional competencies.

Research Hypothesis - H3: There is a significant difference between each key stakeholder group's perceptions of strategic competencies.

\section{Measurement instrument and data collection procedure}

\subsection{Survey instrument}

To conduct survey-based research work, a scientifically developed survey instrument is required. Initiated with a systematic literature review on the three clusters of competencies - including behavioural, functional and strategic competencies were used to list out the key factors identified from the literature review. Further, the researcher tried meeting industry and academic experts to validate the current research survey instrument. The data items were identified in two phases.

Phase 1- A theoretical list of 52 competencies was identified by studying the academic and consultant works.

Phase 2: A mix of the open-ended questionnaire and interview method was used to capture the competencies deemed important by the four stakeholder groups. For an equal representation of the groups, 25 responses from each, i.e. Educators, MBA Alumni, MBA Students ( ${ }^{\text {th }}$ semester), and Recruiters, were recorded and analysed. The total of 100 responses suggested a list of 44 competencies/skills that the stakeholders deemed necessary. When this list was compared with the researchers' list in phase 1, the researchers found 35 items duplicated in both lists. However, 9 new items featured in the list of phase 2 , generating a final list of 61 competencies.

By operationalising the cluster competencies, the researcher can validate and generalise the study constructs. A total of 61 items were listed and grouped under three competency clusters. Twenty-one items were used to measure the behavioural competencies, 21 items were used to measure the 
functional competencies, and 19 items were used to measure the strategic competencies. To operationalise the three constructs, potential stakeholder groups were asked to indicate the degree to which they rank each competency cluster's importance. The respondents' choice could be fixed on one end as 'unimportant' and the other end as 'very important'.

\subsection{Data collection}

A total of 554 key stakeholders from management education were invited to participate in the research. A stratified random sampling technique was adopted to identify the sample. The study confirmed that respondents chosen were having sufficient knowledge and experience in responding. Four hundred thirty-two valid responses (240 males and 192 females) were received and used for analysis. The sample was collected from five universities offering a 2-year full-time MBA degree in Bangalore, India. The sample consisted of academicians from the MBA department at the university level, MBA alumni of these universities with less than one year of work experience, students pursuing MBA programme ( $4^{\text {th }}$ Semester) at these universities, and recruiters who recruit MBA graduates from these universities at entry-level positions.

An invitation to participate in the study was sent to potential participants via email. The introductory email with a link to the questionnaire also explained the research's purpose and time frame. Individuals were asked to complete the questionnaire; the questionnaire was available for completion over four weeks. The questionnaire was developed on a five-point Likert scale (Jackson \& Chapman, 2012) regarding 61 competencies (items) identified by researchers for this study.

\section{Findings and discussion}

An empirical research method was selected to test the hypotheses, and a web-based online questionnaire was used to collect the data. Before data analysis, pre-analysis data screening was performed to ensure the data's accuracy and deal with missing and incomplete data. Data were analysed using Statistical Package for Social Sciences (SPSS) version 23.0 for Windows, a product of SPSS, Inc. Descriptive statistics were applied to compute central tendencies frequencies and measures. The mean comparison was used to explain the descriptive statistic. ANOVA was then employed to test the hypothesis and Tukey test to establish groups with a significant difference in perception.

\subsection{Reliability analysis}

An exploratory factor analysis was performed, and Promax rotation was utilised. The Kaiser-MeyerOlkin (KMO) measurement verified the adequacy of the sample analysed $(n=432, \mathrm{KMO}=.966)$, which is very good or "Marvelous" on Kaiser's (1974) classification of measure values. The Bartlett sphericity test is statistically significant $(\mathrm{p}<.0005)$, indicates that the relationship between items is significantly high for factor analysis.

The component variance was measured with eigenvalue. An eigenvalue of one represents one variable's variance, so with 61 variables, there is a total of 61 eigenvalues of variance. From the analysis, the study observed that the first component explained 33.433 eigenvalues of variance, which is $33.433 / 61 \times 100=54.809 \%$ of the total variance. The second component explained 2.569 eigenvalues of variance, which is $4.704 \%$ of the total variance. Similarly, the third component explained 2.068 eigenvalues of variance, which is $3.391 \%$ of the total variance. Therefore, the three components explained $62.903 \%$ of the total variance. According to Horn (1965), the three components can be retained to analyse the study further.

The reliability analysis of each factor, determined through Cronbach's alpha, indicated a good internal consistency. Factor 1 - Behavioural competencies had 21 items with $\alpha=0.969$; Factor 2 - strategic competencies contained 19 items with $\alpha=0.968$ and Factor 3- functional competencies had 21 items with $\alpha=0.967$. Thus, the data indicated reliability and confirmed that behavioural, strategic and functional competencies fall under the competency cluster. The principle component method with varimax rotation has been adopted, and the items were grouped under three factors: behavioural, 
strategic, and functional. Researchers have found that items in factor 1 significantly contribute to one's behavioural competencies and are all intrinsic. The items of factor 2 significantly contribute towards the common outcome. Through the systematic investigation of the academic and consultant works and considering the employers' expectations, factor 2 is named strategic competencies. The items of factor 3 deal with day to day functions or operation of a business, hence named as functional competencies bucket as shown in Table 3 .

The first factor of human capabilities, named behavioural competencies by the researchers, was the highest contributor. The researcher's findings were not surprising because the importance of behavioural competencies has been confirmed in many works. Hagel et al. (2019) observed that the workforce's value proposition is shifting its focus to 'human capabilities'. Deming (2015) stressed that social and emotional skills are as important as cognitive skills to ensure an individual's productivity and success. Jackson \& Chapman (2012) referred the individual commitments as nontechnical competencies or as behavioural competencies. Leme (2012) referred to behavioural competencies as an employee's attitudes and values. These personal qualities or characteristics influence how successful someone will be in their work. Reliability analysis identified 21 behavioural competencies; factor loading for this cluster is between 0.574 (work-life balance) to 0.748(impactful).

The second factor of strategic competencies was managerial skills which define the fate of organisations success. The major components include evaluation, planning, and execution to achieve the organisational objectives and goals. These competencies facilitate understanding the big picture. Foreseeing the future, visualising the macro perspective, conceptualising the company's holistic view, and being proactive has become of utmost importance in giving an edge to the company (Goldman et al., 2015; Stigter \& Cooper, 2016). Reliability analysis identified 19 strategic competencies. Factor loading for this cluster is between 0.534 (agility) to 0.731 (strategic thinking).

The third factor identified was the functional competencies. Meñez and Tracer (2014) observed that an MBA is a program that equips students with competencies and skills in functional areas such as accounting, business law, marketing, finance, and other business areas. Functional MBAs with single or dual specialisation of functional domains have emerged and are highly sought after by the Industry Gupta, Saunders and Smith (2007). Functional competencies are job-specific competencies that drive proven high-performance, quality results for a given position. Reliability analysis identified 21 functional competencies. Factor loading for this cluster is between 0.504 (quality orientation) to 0.757(global exposure).

\subsection{Summary of the importance level of competencies as perceived by the key stakeholder groups}

The descriptive analysis results gave a list of the top 10 essential competencies perceived by the key stakeholder groups of management education Table 2. The findings were associated with the first objective of the paper.

Table 2. Rank the top 10 competency items of three clusters using mean scores

\begin{tabular}{clrc}
\hline Rank & GROUP I - MBA Educators & Mean (M) & $\begin{array}{c}\text { Standard } \\
\text { Deviation (SD) }\end{array}$ \\
\hline 1 & BC_Building Positive Working Relationships & 4.49 & 0.81 \\
2 & BC_Positive Work Attitude & 4.49 & 0.81 \\
3 & FC_Effective Communication & 4.49 & 0.75 \\
4 & BC_Commitment To Work Contract & 4.44 & 0.84 \\
5 & SC_Timely Response & 4.44 & 0.81 \\
6 & BC_Adaptation to Ethics and Values & 4.41 & 0.87 \\
7 & BC_Work Life Balance & 4.41 & 0.90 \\
8 & FC_Continuous Learning & 4.38 & 0.89 \\
9 & FC_Domain Knowledge & 4.31 & 0.82
\end{tabular}




\begin{tabular}{|c|c|c|c|}
\hline Rank & GROUP II - MBA Alumni & Mean (M) & $\begin{array}{c}\text { Standard } \\
\text { Deviation (SD) }\end{array}$ \\
\hline 1 & FC_Effective Communication & 4.36 & 1.02 \\
\hline 2 & BC_Positive Work Attitude & 4.31 & 0.96 \\
\hline 3 & FC_Continuous Learning & 4.28 & 1.01 \\
\hline 4 & FC_Building a Successful Team & 4.23 & 1.05 \\
\hline 5 & FC_Understanding Business Dynamics & 4.21 & 0.91 \\
\hline 6 & BC_Building Positive Working Relationships & 4.18 & 1.15 \\
\hline 7 & SC_Analytical Skills & 4.18 & 1.06 \\
\hline 8 & BC_Work Life Balance & 4.15 & 1.17 \\
\hline 9 & FC_Decision Making & 4.15 & 0.92 \\
\hline 10 & FC_Managing Work & 4.13 & 0.91 \\
\hline 11 & SC_Facilitating Change & 4.13 & 1.09 \\
\hline 12 & SC_Strategic Thinking & 4.13 & 1.02 \\
\hline Rank & GROUP III - MBA Students & Mean (M) & $\begin{array}{c}\text { Standard } \\
\text { Deviation (SD) }\end{array}$ \\
\hline 1 & BC_Work Life Balance & 4.21 & 0.92 \\
\hline 2 & FC_Effective Communication & 4.18 & 0.92 \\
\hline 3 & FC_Decision Making & 4.16 & 0.88 \\
\hline 4 & BC_Motivating People & 4.14 & 0.95 \\
\hline 5 & BC_Creativity & 4.13 & 0.96 \\
\hline 6 & BC_Positive Work Attitude & 4.13 & 1.00 \\
\hline 7 & FC_Building a Successful Team & 4.12 & 0.89 \\
\hline 8 & FC_Continuous Learning & 4.12 & 0.90 \\
\hline 9 & BC_Understanding People & 4.06 & 1.03 \\
\hline 10 & BC_Building Positive Working Relationships & 4.04 & 1.08 \\
\hline Rank & GROUP IV - Recruiters & Mean (M) & $\begin{array}{c}\text { Standard } \\
\text { Deviation (SD) }\end{array}$ \\
\hline 1 & BC_Positive Work Attitude & 4.27 & 1.17 \\
\hline 2 & SC_Timely Response & 4.27 & 0.86 \\
\hline 3 & FC_Effective Communication & 4.09 & 0.85 \\
\hline 4 & BC_Proactive & 4.05 & 1.07 \\
\hline 5 & FC_Quality Orientation & 4.00 & 1.04 \\
\hline 6 & BC_Building Positive Working Relationships & 3.95 & 1.02 \\
\hline 7 & BC_Commitment To Work Contract & 3.91 & 1.31 \\
\hline 8 & SC_Keeping Pace With Changing Trends & 3.91 & 0.90 \\
\hline 9 & FC_Initiating Action & 3.86 & 0.92 \\
\hline 10 & SC_Critical Thinking & 3.86 & 0.69 \\
\hline
\end{tabular}

Note: B.C. stands for Behavioural Competency, F.C. stands for Functional Competency and S.C. stands for Strategic Competency

\section{A. Summary of key behavioural competencies}

An in-depth analysis of the findings of stakeholders perspectives brings into light that Positive Work Attitude, Building Positive Working Relationships, Teamwork and Collaboration, Work-life Balance, Creativity, Commitment to work contract, Motivating people are the key behavioural competencies 
rated as important by the key stakeholder groups of this study. (Mean of rating more than 4 by any key stakeholder group) as illustrated in Table 2

1 Positive Work Attitude: Exhibiting an optimistic disposition in every situation, attracting positive changes and increasing achievement is a positive work attitude (Seema Sanghi, 2016). Feeling positive, having a positive opinion about work, and behaving positively at work is necessary for fresh MBA graduates to excel in their careers. The key stakeholder groups have perceived positive work attitude to be important behavioural competency for the fresh MBA graduates - educators ( $M=4.49$, $\mathrm{SD}=.818)$, MBA Alumni $(\mathrm{M}=4.31, \mathrm{SD}=.96)$, Recruiters $(\mathrm{M}=4.27, \mathrm{SD}=1.17)$ and $\mathrm{MBA}$ Students $(\mathrm{M}=4.13, \mathrm{SD}=1)$.

2 Building Positive Working Relationships/Teamwork and Collaboration: developing and using collaborative relationships to facilitate the accomplishment of work goals (Harvard University Competency Dictionary) at workplace is the key to developing, maintaining and strengthening partnerships with others inside or outside the organisation. Such collaborations provide assistance, support and information vital for day to day operations (Mihir Sharma, 2017). The key stakeholders have perceived this to be important behavioural competency- MBA Educators $(\mathrm{M}=4.49, \mathrm{SD}=.81)$, MBA Alumni $(\mathrm{M}=4.18, \mathrm{SD}=1.15)$, MBA Students $(\mathrm{M}=4.04, \mathrm{SD}=1.08)$ and Recruiters $(\mathrm{M}=3.95$, $\mathrm{SD}=1.03$ ).

3 Work-life Balance: it is the balance of time that one dedicates to doing a job and the time one spends with family or while doing things that one enjoys. The definitions of work-life balance have been segregated based on two dimensions a. When there are multiple roles in work and non-work life, the role engagement matters $b$. the conflict between the work roles and non-work roles should be minimalistic (Sirgy \& Lee, 2018). Maintaining work-life balance is deemed as important competency by the key stakeholder groups - MBA Educators $(M=4.41, S D=.9)$, MBA Students $(M=4.21$, $\mathrm{SD}=.92)$, MBA Alumni $(\mathrm{M}=4.15, \mathrm{SD}=1.17)$ and Recruiters $(\mathrm{M}=3.18, \mathrm{SD}=1.24)$.

4 Commitment to work contract: a promise or firm decision to do something and willingly devote time and energy to a job or activity as prescribed or expected in the job profile for a given period. It can also be explained as delivering results on commitment (Seema Sanghi, 2016). The key stakeholders have perceived this to be important behavioural competency- MBA Educators ( $M=4.44$, $\mathrm{SD}=.84)$ and Recruiters $(\mathrm{M}=3.91, \mathrm{SD}=1.31)$.

5 Creativity: the ability to produce or use original and unusual ideas is creativity. Creativity generates innovative solutions in work situations; tries different and novel ways to deal with work problems and opportunities (Seema Sanghi, 2016) . This act of turning new and imaginative ideas into reality, perceiving the world in new light deciphering hidden patterns and connecting the dots to generate a solution is creativity. The process of creativity by design encourages collaboration and cooperation in the workplace. This competency is perceived to be important by the stake holder groups for the budding managers- MBA Students $(\mathrm{M}=4.13, \mathrm{SD}=.96)$

6 Motivating people: There is a need to understand the need to motivation others in the workplace. To improve the bottom line of the organisation through enhanced individual motivation (ASTD, 1990) This ability to influence people in a certain way that has an effect on their outcomes at the workplace is of high importance. The key stakeholders have perceived motivating people as a key competency for the fresh MBA graduates MBA Students $(\mathrm{M}=4.14, \mathrm{SD}=.95)$

7. Proactive: At the individual level, this focus on competencies enables people to take a proactive role in their own development by providing guidance in behaviour change efforts (Harvard University Competency Dictionary). Displaying the ability to evaluate future implications of current decisions and action causing change and not only reacting to change when it happens makes the organisation ready and equipped for future, but this is also an important competency which should be there in an MBA graduate for sustained employability. - Recruiters $(\mathrm{M}=4.05, \mathrm{SD}=1.07)$.

8 Adaptation to Ethics and Values: Keeping the organisation's vision and values at the forefront of decision-making and action- Leading/Living The Vision And Values (Harvard University Competency Dictionary) Adhering to organisations mission, culture, ethos and code of conduct adaptation to organisations vision (Seema Sanghi, 2016). The understanding of what is morally right and wrong (ethics) and knowing the principles that help to decide what is right and wrong, and how to act in various situations (values) of the workplace are very crucial, thereby adapting according to 
them is deemed as an important competency by the stakeholder groups for the fresh MBA graduates. MBA Educators $(\mathrm{M}=4.41, \mathrm{SD}=.87)$

9 Understanding People: Build effective relationships with key internal partners to enhance collaboration and understanding (Harvard University Competency Dictionary). Relating well to all kinds of people helps foster a positive relationship between people and groups. They feel sympathy for each other, laying a foundation for strong and productive work culture. This competency is important for managers to flourish in their careers- MBA Students $(\mathrm{M}=4.06, \mathrm{SD}=1.030)$ (Shafer $\underline{2017)}$.

\section{B. Summary of key functional competencies}

A detailed study of the findings of stakeholders perspectives brings into light that Effective Communication, Continuous learning, Building successful teams and decision making are the key competencies rated as important from the bucket of Functional competencies by the key stakeholder groups of this study. (Mean of rating more than 4 given by any key stakeholder group) as illustrated in Table 2.

1 Effective Communication: it is clearly conveying information and ideas through a variety of media to individuals or groups in a manner that engages the audience and helps them understand and retain the message (Harvard University Competency Dictionary). A consistent, candid, clear and open communication while maintaining the interest and attention of others (Seema Sanghi, 2016) is important in the workplace. The key stakeholder groups have perceived effective communication as an important competency for fresh MBA graduates employability- MBA Educators ( $M=4.49$, $\mathrm{SD}=.75)$, MBA Alumni $(\mathrm{M}=4.36, \mathrm{SD}=1.02)$, MBA Students $(\mathrm{M}=4.18, \mathrm{SD}=.92)$, Recruiters $(\mathrm{M}=$ $4.09, \mathrm{SD}=.85$ ).

2 Continuous learning: actively identifying new areas for learning; regularly creating and taking advantage of learning opportunities; using newly gained knowledge and skill on the job and learning through their application (Harvard University Competency Dictionary). Working with an attitude to learn new things directs to continuous improvement witch is perceived as an important competency for fresh MBA graduates - Educators $(\mathrm{M}=4.38, \mathrm{SD}=.89)$, MBA Alumni $(\mathrm{M}=4.28, \mathrm{SD}=1.01)$ and $\mathrm{MBA}$ Students (M=4.12, $\mathrm{SD}=.9)$.

3 Building successful teams: using appropriate methods and a flexible interpersonal style to help build a cohesive team; facilitating the completion of team goals (Harvard University Competency Dictionary). The teams and individuals need to be encouraged for higher performance standards by setting and communicating challenging goals. This is essential for achieving the shared goals. The key stakeholders have perceived this competency to be an important one in building sustainable employability of fresh MBA graduates. - MBA Educators $(\mathrm{M}=4.28, \mathrm{SD}=.85)$, MBA Alumni $(\mathrm{M}=4.23, \mathrm{SD}=1.05)$ and MBA Students $(\mathrm{M}=4.12, \mathrm{SD}=.89)$

4 Decision making: Using effective approaches for choosing a course of action or developing appropriate solutions and/or reaching conclusions; taking action consistent with available facts constraints and anticipated consequences (Seema Sanghi, 2016). Identifying and understanding issues, problems, and opportunities; comparing data from different sources to draw conclusions; using effective approaches for choosing a course of action or developing appropriate solutions; taking action that is consistent with available facts, constraints, and probable consequences. This competency plays a vital role in enhancing the employability skills of fresh MBA graduates. The key stakeholder groups have perceived this to be important competency- MBA Alumni ( $\mathrm{M}=4.15, \mathrm{SD}=.92)$ and $\mathrm{MBA}$ Students $(\mathrm{M}=4.16, \mathrm{SD}=.88)$.

5 Domain Knowledge: also referred to as subject knowledge, it is required to do the job at a satisfactory level of accomplishment (Seema Sanghi, 2016). Having achieved a satisfactory level of technical and professional skill or knowledge in position-related areas; keeping up with current developments and trends in areas of expertise (Harvard University Competency Dictionary). Domain knowledge is an essential competency as per the stakeholders' groups for enhanced employability of MBA graduates. The key stakeholder groups perception - MBA Educators ( $\mathrm{M}=4.31, \mathrm{SD}=.82)$.

6 Managing Work: Use Managing Work (Includes Time Management) when the focus within the job/role is on the incumbent's planning of his or her own time and work, not determining the schedules or activities of others expertise (Harvard University Competency Dictionary). It basically 
means effectively managing one's time and resources to ensure that work meets or exceeds expectations. The key stakeholder groups have perceived this to be important competency- MBA Alumni (M=4.13, $\mathrm{SD}=.91)$

7 Understanding Business Dynamics: Understanding the forces or processes that produce change inside a business is perceived as an important competency by the stake holder groups for the sustainable employability of the fresh MBA graduates. The knowledge and awareness of local and global business environments -(economic, legal and social ) that enables in recognising the functioning of businesses, identifying potential business opportunities, the evolvement of business enterprises and exploring the entrepreneurial opportunities is deemed as an important outcome of Management education (AICTE, 2018). The key stakeholder groups perception - MBA Alumni $(\mathrm{M}=4.21, \mathrm{SD}=.91)$

8 Initiating Action -Taking prompt action to accomplish objectives; taking action to achieve goals beyond what is required; being proactive (Harvard University Competency Dictionary) is rated high by the Recruiters $(\mathrm{M}=3.86, \mathrm{SD}=.92)$.

9 Quality Orientation- Displays affinity for seeing details, grading them against a pre-set standard and identifying flaws (Seema Sanghi, 2016) is rated as important by the Recruiters (M=4, SD=1.04).

\section{Summary of key strategic competencies}

The analysis of stakeholders' perspectives suggests that timely response, ability to solve complex problems, critical thinking, fostering innovation, keeping pace with changing trends, strategic planning, and strategic thinking are the key functional competencies rated as important by the key stakeholder groups this study. (Mean of rating more than 4 given by any key stakeholder group), as depicted in Table 2.

1 Timely response: Sense of timing exhibits the ability to accurately evaluate what is happening in such a way that statements, decisions, and actions are the most effective, accurate and timely (Seema

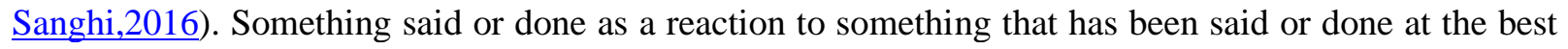
possible moment is considered a key competency for budding MBA graduates, which is perceived as important by the key stakeholder groups - MBA Educators $(\mathrm{M}=4.44, \mathrm{SD}=.81)$ and Recruiters $(\mathrm{M}=$ 4.27, S.D. = .86).

2 Critical thinking: Critically analyse the problems and come out with a solution (Seema Sanghi 2016) while analysis is interpreting and evaluating complex information, thereby arriving at logical deductions and conclusions (Seema Sanghi, 2016). This ability to think carefully about a subject or idea without allowing feelings or opinions to affect oneself is deemed important by the key stakeholder groups - Recruiters $(\mathrm{M}=3.86$, S.D. $=.69)$.

3 Keeping pace with changing trends: Keeping oneself abreast of external and internal futuristic and present needs of all the customers and that of the organisation (Seema Sanghi, 2016) to manage to do things at the same time or speed or as quickly as necessary due to general development or change in a situation is perceived as an important competency- Recruiters ( $\mathrm{M}=3.91, \mathrm{SD}=.9)$

4 Strategic thinking: Analysing the organisation's competitive position by considering the market and industry trends, existing and potential customers (internal and external), and strengths and weaknesses as compared to competitors (Seema Sanghi, 2016) Strategic thinking is perceived to be an important competency for fresh MBA graduate employability as it directly affects the organisational growth. The key stakeholder groups perception -MBA Alumni $(\mathrm{M}=4.13, \mathrm{SD}=1.03)$.

5 Facilitating Change - Assisting a group or individuals to accomplish specific goals and managing change by providing the needed structure and environment to ensure its effectiveness (Seema Sanghi, $\underline{2016)}$ is rated highly by MBA Alumni $(\mathrm{M}=4.13, \mathrm{SD}=1.09)$.

6 Analytical Skills - Enable analyses, interpretation and evaluation of complex information to arrive at logical deduction and conclusion (Seema Sanghi, 2016) is rated highly by MBA Alumni (M = 4.18, $\mathrm{SD}=1.06)$. 


\subsection{Study of perceptions of key stakeholders' group towards the 3 factors (behavioural, functional and strategic)}

The analysis suggests that academicians have given a higher rating to behavioural competencies( $\mathrm{M}=$ 4.13), functional competencies( $M=4.07)$, and strategic competencies $(M=4.00)$. Further, the analysis reveals that all the key stakeholders' groups of management education rated functional competencies as most important $(\mathrm{M}=3.92)$ next behavioural competencies $(\mathrm{M}=3.91)$ and strategic competencies at the end $(M=3.83)$.

One-way ANOVA is run to test the hypotheses and statistically establish the difference in perception of various stakeholders. The significance value in the homogeneity of variance test must be greater than .05 , which indicates the constructs' variances are approximately equal. Tukey test is run by researchers, the variance of the competency clusters to be approximately equal. This drives the study's second objective to test the difference in the perception of the four key stakeholder groups of management education.

The ANOVA test suggests that the null hypothesis is rejected, significance value being less than .05 , as shown in table 3 . There is sufficient evidence found to accept all three research hypothesises.

Research Hypothesis (H1) is accepted: There was a significant difference between each primary stakeholder group's perceptions towards the behavioural competencies. A significant difference in perception of academicians and recruiters is noted $(\alpha=004)$ Figure 2.

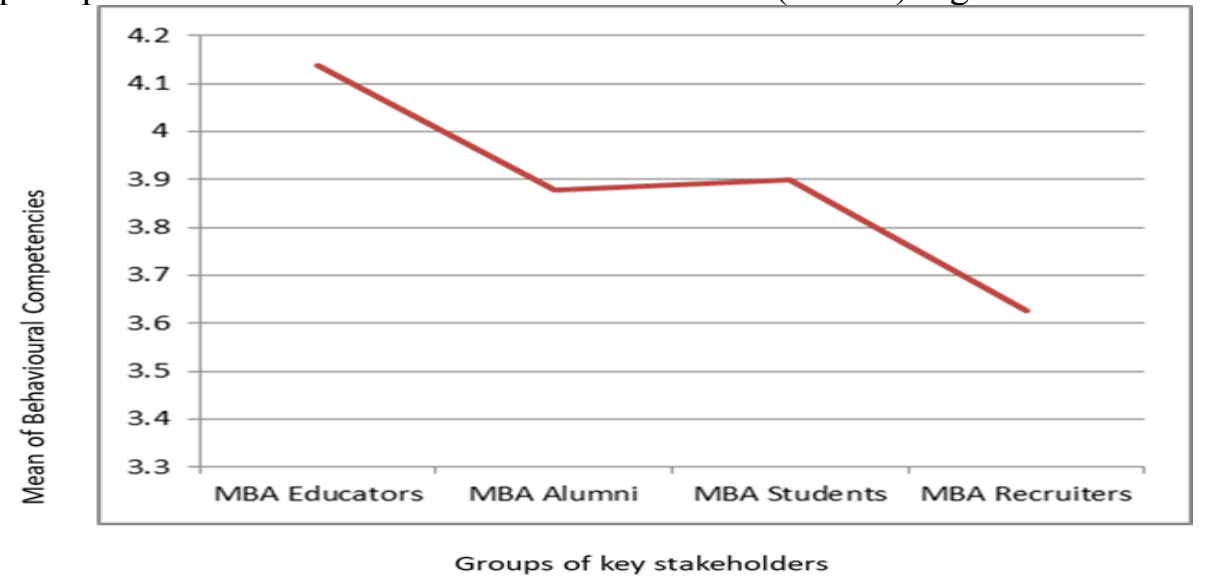

Figure 2. Depiction of perception means of four key stakeholder groups towards Behavioural Competencies

Research Hypothesis (H2) is accepted: There was a significant difference between each primary stakeholder group's perceptions towards the functional competencies. A significant difference in perception of academicians and recruiters $(\alpha=.000)$, recruiters and MBA alumni $(\alpha=.004)$ and MBA students and recruiters $(\alpha=.004)$ is noted in Figure 3. 


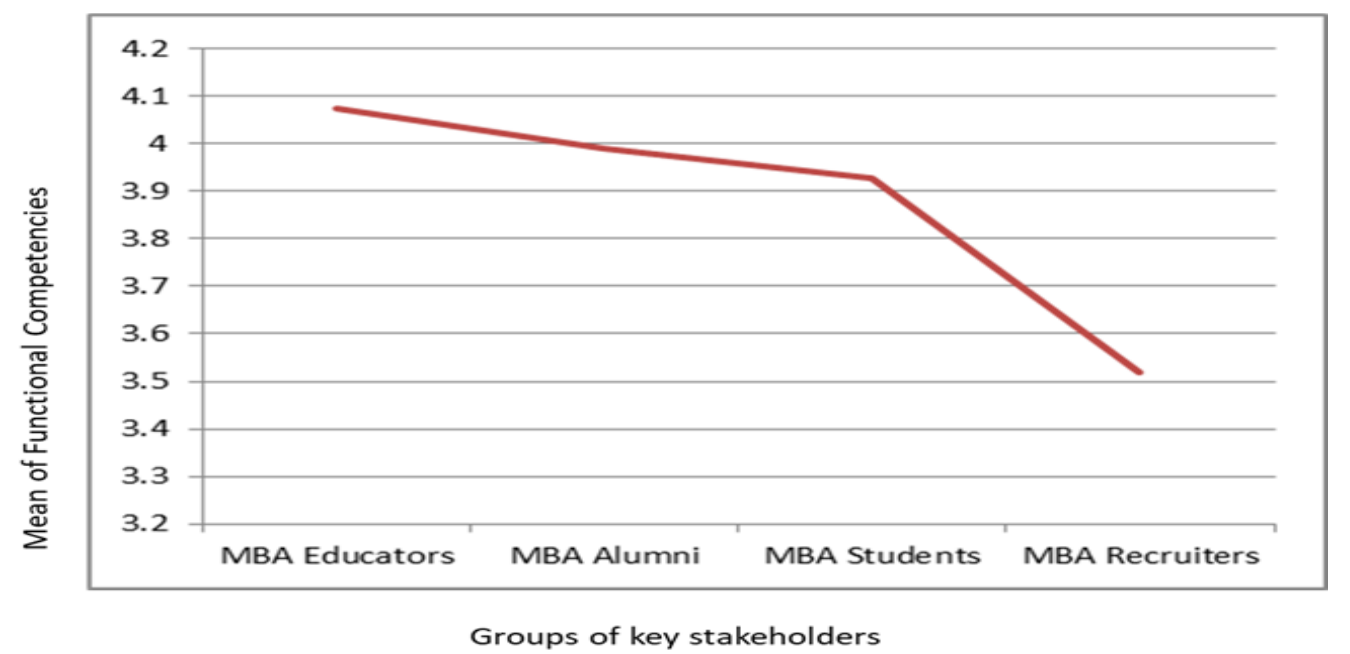

Figure 3. Depiction of perception means four key stakeholder groups towards functional competencies

Research Hypothesis (H3) is accepted: There was a significant difference between each primary stakeholder group's perceptions towards the strategic competencies. A significant difference in perception of academicians and recruiters $(\alpha=004)$ and MBA alumni and recruiters $(\alpha=.016)$, is noted in Figure 4.

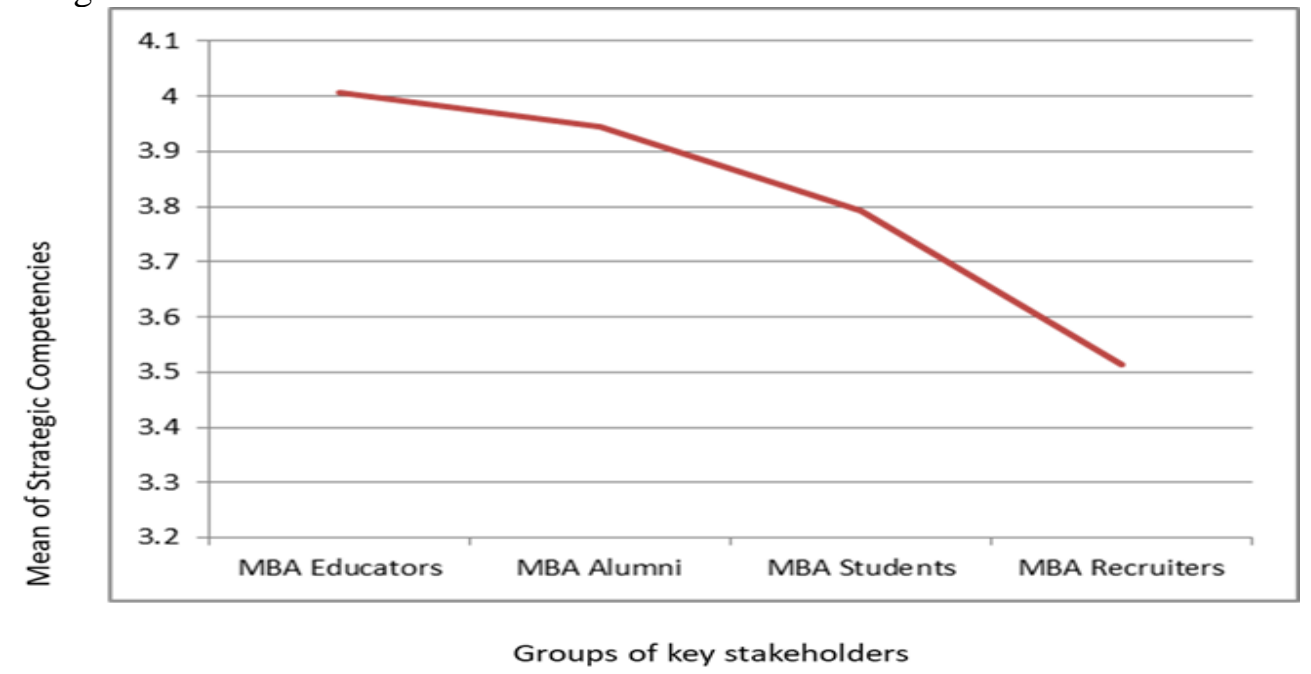

Figure 4. Depiction of perception means four key stakeholder groups towards strategic competencies

One of the main reasons for the difference in educators and recruiter's perception can be that employers focus on the relevance of education while educators focus on the rigour of education. Clinebell \& Clinebell (2008) noted that management education has continuously tried to balance relevance and rigour. This difference is re-established in the study, as stated by Hofstrand (1996), who observed the difference between an entry-level graduate's skills set to be different from the recruiters' expectations. 
Table 3. Stakeholders perceptions towards the three competency clusters using ANOVA

\begin{tabular}{llrrrrr}
\hline & \multicolumn{1}{c}{ ANOVA } & & & & \\
\hline & & $\begin{array}{c}\text { Sum of } \\
\text { Squares }\end{array}$ & df & $\begin{array}{c}\text { Mean } \\
\text { Square }\end{array}$ & F & Sig. \\
\hline Behavioural & Between Groups & 7.714 & 3 & 2.571 & 3.999 & .008 \\
Competencies & Within Groups & 275.215 & 428 & .643 & & \\
& Total & 282.929 & 431 & & & \\
Functional & Between Groups & 9.313 & 3 & 3.104 & 5.880 & .001 \\
Competencies & Within Groups & 225.946 & 428 & .528 & & \\
& Total & 235.259 & 431 & & & \\
Strategic & Between Groups & 8.239 & 3 & 2.746 & 4.681 & .003 \\
Competencies & Within Groups & 251.122 & 428 & .587 & & \\
& Total & 259.362 & 431 & & & \\
\hline
\end{tabular}

\subsection{Top ten key competencies suggested for sustainably employable MBA graduates by stakeholders of management education}

The mean comparison method was used to identify and suggest the ten' key competencies, which are most important and expected by all the stakeholder groups. Enabling and equipping the graduates with the following capabilities would ease the pressure of hiring the right talent in the industry, which is the third objective of the study. They are Positive Work Attitude: $(\mathrm{M}=4.30, \mathrm{SD}=0.99)$, Effective Communication: $(\mathrm{M}=4.28, \mathrm{SD}=0.91)$, Timely response: $(\mathrm{M}=4.21, \mathrm{SD}=0.96)$, Building Positive Working Relationships / Teamwork and Collaboration: $(\mathrm{M}=4.17, \mathrm{SD}=1.06)$, Continuous learning $(\mathrm{M}=4.15, \mathrm{SD}=0.98)$, Commitment to work contract: $(\mathrm{M}=4.09, \mathrm{SD}=1.06)$, Quality orientations $(\mathrm{M}=4.07, \mathrm{SD}=0.96)$, Building successful teams: $(\mathrm{M}=4.04, \mathrm{SD}=0.96)$, Adaptation to Ethics and Values: $(\mathrm{M}=4.01, \mathrm{SD}=0.97)$ and Managing Work: $(\mathrm{M}=4, \mathrm{SD}=0.85)$.

\section{Conclusion and suggestions}

Industry and academia cannot work in isolation and are considered as prominent pillars of the economy. A robust collaboration between the two can ensure mutual and overall growth. Innovation in academia has directly impacted businesses for years, and both need to recognise and acknowledge this opportunity. This paper attempts to make a constructive framework of collaboration between the two, creating a work-ready workforce for the industry. The study derives the importance levels of competencies as perceived by the four key stakeholder groups of management education i.e. Academicians, MBA Alumni, MBA Students and Recruiters. The paper statistically establishes a significant difference in academicians and recruiters' perception in all the three factors (behavioural, functional and strategic) of competencies.

One of the primary reasons for the difference in educators and employers' perception could be that employers focus on education's relevance while educators' focus is primarily on education's rigour. It is important to redesign and realign the MBA curriculum in a way that strikes the right balance between relevance and rigour. The study suggests that ten key competencies are most important and contribute towards meeting industry expectations of sustainable employability of its fresh hires with empirical evidence. Inclusion of these (in the curriculum) is likely to improve management programs' outcomes as expected by the industry. The collaboration between industry and academia is not always rosy, but it is possible when done with clear objectives. This kind of mutually beneficial approach can produce groundbreaking results that can solve the complex problem of bridging the employability skill gap and meeting the industry expectation of sustainable employability. While the industry and academia enjoy the symbiotic relationship, society and economy benefit from the skilled and sustainably employable workforce relevant to industrial and national interest areas.

The outbreak of the Coronavirus has significantly accelerated the development of online education in Indian higher education. Internet, big data, A.I., 5G, and cloud-based platforms, among other 
technologies, have been put to use in the teaching and learning process. Though a more adaptable learning approach does not result only with infrastructure, the student and teacher's online competency plays a critical role. This new teaching-learning process could reflect a move away from conventional classroom lecturing towards more student-centred activities such as social activities, meetings, hands-on learning activities, and traditional lectures in moderation. This necessitates a conceptual and cognitive rethinking of students, learners, and teachers functional and strategic competencies in the postdigital learning communities (Jandric et al. 2018; Nicholls 2018; Zhu \& Liu, $\underline{2020)}$.

\section{Limitations and future research}

The study has been conducted systematically in two phases - the qualitative and quantitative phases and the sample size seems to be adequate for the current study. However, the current study did not take proportionate samples based on the number of private, state, central universities listed and affiliated colleges listed under AICTE. Most of the study samples are located in Bangalore. Future studies need more emphasis on distributing the samples as per the number of institutions, universities and affiliation colleges that run MBA programs and their fee structures listed AICTE or UGC. Also, studies can explore the role of premier institutions, private, state, central universities and affiliated colleges in delivering the identified competencies. Further studies can also look into teaching-learning practices to enhance student competencies.

\section{References}

Akimova, I. (2000). Development of market orientation and competitiveness of ukrainian firms. European Journal of Marketing, 34 (9/10),1128-1148.

Akkermans, J., \& Kubasch, S. (2017). Trending topics in careers: A review and future research agenda. Career Development International, 22(6), 586-627. https://doi.org/10.1108/CDI-082017-0143.

Al-Abri, N., \& Kooli, C. (2018). Factors affecting the career path choice of graduates: a case of Omani. Int. J. Youth Eco, 2, 105-117.

American Assembly of Collegiate Schools of Business. (1987). Outcome measurement project. Phase III Report.

Anderson, D. M., \& Slade, C. P. (2016). Managing institutional research advancement: Implications from a university faculty time allocation study. Research in higher education, 57(1), 99-121.

Anthony, P. C., Leila, J. G. \& Ann, S. M. (1990). Workplace basics: the essential skills employers want. astd best practices series: training for a changing work force. First Edition, Publishers 350 Sansome Street San Francisco, California.

B Gupta, V., Gollakota, K., \& Sreekumar, A. (2003). Quality in business education:a study of the indian context. business education and emerging market economies: trends and prospects conference. Atlanta, Georgia, USA. Retrieved May 26, 2020

Baruch,Y., Bell, M.P. \& Gray, D. (2005). Generalist and specialist graduate business degrees: tangible and intangible value. Journal of Vocational Behavior, 67(1), 2005, 51-68.

Boyatzis, R. E. (2008). Competencies in the 21 st century. Journal of Management Development, $27(1), 5-12$.

Boyatzis, R. E. (2009). Competencies as a behavioral approach to emotional intelligence. Journal of Management Development, 28(9), 749-770.

Boyatzis, R.E. (1982). The competent manager: a model for effective performance. New York: John Wiley and Sons.

Bridgstock, R. (2009). The graduate attributes we've overlooked: Enhancing graduate employability through career management skills. Higher Education Research \& Development, 28(1), 31-44. https://doi.org/10.1080/07294360802444347.

Buller PF and McEvoy GM. (2012). Strategy, human resource management and performance: sharpening line of sight. Human Resource Management Review, 22(1): 43-56.

Clinebell, S.K., \& Clinebell, J.M. (2008). The tension in business education between academic rigour and real-world relevance: The role of executive professors. Academy of Management Learning \& Education, 7(1), 99-107. 
Collins, J. (2001). Level 5 leadership-the triumph of humility and fierce resolve. Harvard Business Review, 67-76.

Deaconu, Adela , Osoian, Codruta,Zaharie, Monica Achim, Sorin Adrian. (2014). competencies in higher education system: an empirical analysis of employers' perceptions. Amfiteatru Economic Journal, 2247-9104 16 (37), 857-873

Deming, D.J. (2015). The growing importance of social skills in the labor market. NBER Working Paper 21473, National Bureau of Economic Research.

Droge, C.; Vickery, S. and Markland, R.E. (1994). Sources and outcomes of competitive advantage: an exploratory study in the furniture industry. Decision Sciences, 25(5/6), 669-689.

Dutt, R. (2018). After millennials, Gen Z is about to reshape businesses. Business Insider.

Fleming J, Martin AJ, Hughes H, et al. (2009). Maximizing work integrated learning experiences through identifying graduate competencies for employability: a case study of sport studies in higher education. Asia-Pacific Journal of Cooperative Education 10(3), 189-201.

Goldman, E. F., Scott, A. R., \& Follman, J.M. (2015). Organizational practices to develop strategic thinking. Journal of Strategy and Management, 8(2), 155-175.

Gupta, PB, Saunders, PM \& Smith, J. (2007). Traditional master of business administration (mba) versus the mba with specialization: a disconnection between what business schools offer and what employers seek. Journal of Education for Business, 82(6), 307-312.

Hagel, J., Brown, J.S., \& Wooll, M. (2019). Skills change, but capabilities endure: Why fostering human capabilities first might be more important than reskilling in the future of work. Deloitte Insights.

Hamel, G., \& Heene, A. (1994). Competence-based competition. Wiley.

Hamel, G., \& Prahalad, C. K. (1994). Competing for the future. Harvard business review, 72(4), 122128.

Harrell, M. \& Barbato, L. (2018). Great managers still matter: The evolution of Google's Project Oxygen, re:Work with Google.

Harvard University Competency Dictionary (C) Development Dimensions Int'l, Inc.2008

Hitt, M.A. and Irelend, R.D. (1985). Corporate distintive competence, strategy, industry and performance. Strategic Management Journal, 6(3), 273-293.

Hofstrand R. (1996). Getting all the skills employers want. Techniques. Making Education \& Career Connections, 71: 51.

Horn, J. L. (1965). A rationale and test for the number of factors in factor analysis. Psychometrica, $30,179-185$.

https://facilities.aicte-india.org/dashboard/pages/dashboardaicte.php

Jackson, D., \& Chapman, E. (2012). Non-technical competencies in undergraduate business degree programs: Australian and U.K. perspectives. Studies in Higher Education, 37, 541-567. doi:10.1080/03075079.2010.527935

Jandrić, P., Knox, J., Besley, T., Ryberg, T., Suoranta, J., \& Hayes, S. (2018). Postdigital science and education.

Kaiser, H. F. (1974). An index of factorial simplicity. Psychometrica, 39, 31-35.

Kautz, T. (2020). Fostering and measuring skills: Improving cognitive and non-cognitive skills to promote lifetime success. OECD.

Kooli, C. (2019). Governing and managing higher education institutions: The quality audit contributions. Evaluation and program planning, 77, 101713.

Kooli, C. (2020). The philosophy of education in the sultanate of Oman: Between perennialism and progressivism. American Journal of Education and Learning, 4(1), 36-49.

Lado, A. A., \& Wilson, M. C. (1994). Human resource systems and sustained competitive advantage: a competencybased perspective. Academy of Management Review, 19, 699-727.

Le Deist F, D., \& Winterton, J. (2005). What is competence?. Human Resource Development International, 8(1), 27-46.

Leme, R. (2012). Aplicação prática de gestão de pessoas por competências:Mapeamento, treinamento, seleção, avaliação emensuração de resultados de treinamento [Practical application of people management by competences: Mapping, training, selection, evaluation and measurement of training results] (2a ed.). Rio de Janeiro, Brazil: Quality Mark. 
Li, L.X. (2000). An analysis of sources of competitiveness and performance of chinese manufacturers. International Journal of Operations and Production Management, 20(3), 299-315.

Macatangay, L.P. (2013). Study of BSCS graduates of lyceum of The Philippines University from 2004-2009. Academic Research International, 4(5), 2013, 361.

Malerba, F. and Marengo, L. (1995). Competence, innovation activities and economic performance in itallian high-technology firm. International Journal of Technology Management, 10(4-6), 461-477.

McCauley, C. D., Moxley, R. S., \& Van Velsor, E. (1998). The center for creative leadership handbook of leadership development.San Francisco, CA: Jossey-Bass.

McClelland DC. (1973). Testing for competence rather than for 'intelligence'. American Psychologist 28(1), 1.

McLagan, P. A. (1997). Competencies: the next generation. Training and Development, 51(5), 40-48.

Meñez N.L., \& Tracer. (2014). Study of the masters in business administration (MBA) Graduates from 2008-2012, Asia Pacific Journal of Education, Arts and Sciences, 1(1), 14-18, 2014.

Metri, B., Sridhar,M.K., M, Jayadev. \& Sheriff, M.A. (2018) January. Model curriculum for management program (MBA \& PGDM) All India Council for Technical Education, Nelson Mandela Marg, Vasant Kunj, New Delhi-110070 www.aicte-india.org.

Mihir Sharma. (2017). Whether that's a good or bad thing remains to be seen https://www.bloomberg.com/opinion/articles/2017-09-08/india-s-youth-are-the-world-sfuture

Nicholls A. (2018). Managing educational innovations, New York: Routledge Library Editions: Education Management, Volume Taylor \& Francis Group.

Pfeffer, J., \& Sutton, R. I. (2000). The knowing-doing gap: How smart companies turn knowledge into action. Boston MA: Harvard Business School Press.

Radin, J., Hatfield, S., Schwartz, J., \& Bordeaux, C.(2020) .Closing the employability skills gap The answer is simpler than you may think. https://www2.deloitte.com/.

Rothwell, A., \& Arnold, J. (2007). Self-perceived employability: Development and validation of a scale. Personnel Review, 36(1), 23-41.

Ryan, G., Emmerling, R.J. \& Spencer, L.M. (2009). Distinguishing high-performing European executives: the role of emotional, social and cognitive competencies. Journal of Management Development, 28(9): 859-875.

Sanghi, S. (2016). The Handbook of competency mapping .New Delhi, India . SAGE Publications India Pvt Ltd.

Shafer, L. (2017)._Interpersonal skills and today's job market - jobs requiring high levels of

Sirgy, M. J., \& Lee, D. J. (2018). The psychology of life balance. e-Handbook of subjective wellbeing. NobaScholar. social interaction are growing. What does that mean for schools?

Spencer, L.M., \& Spencer, S,M. (1993). Competence at work. New York: John Wiley and Sons.

Stigter, M., \& Cooper, C. L. (2016). Solving the strategy delusion: mobilizing people and realizin distinctive strategies. London: Palgrave.

The Deloitte Global Millennial Survey. (2019). Societal discord and technological transformation create a "generation disrupted", accessed August 29,2019.

The employment mismatch. (2013). Chronicle of higher education

The Higher Education Forum supported by 1 SOS \& Westat. (2010). Skill gap survey: survey for the indian banking, financial services, and insurance Sector.

Thi Mai Anh NGUYEN (2008). Functional competencies and their effects on performance of manufacturing companies in Vietnam Thesis presented to the Faculty of Economics and Social Sciences at the University of Fribourg (Switzerland) in fulfilment of the requirements for the degree of Doctor of Economics and Social Sciences

Thomas, H., Thomas, L., \& Wilson, A. (2013). The unfulfilled promise of management education (M.E.): The role, value and purpose of M.E. Journal of Management Education, 32(5), 460476.

Vikas Gupta, Jeff Schwartz, Rajat Mishra, and Jagadish Upadhyaya. (2019). Laying the foundation for the future of work in India, Insights from the 2019 Deloitte Deans' Summit.

Wheebox, India skills report 2020. 
Wikipedia. (2020). Business school.

Wiley Education Services \& Future Workplace. (2019). Closing the skill gap 2019. Louisville, KY; Wiley edu LLC.

Wille, B., De Fruyt, F., \& Feys, M. (2013). Big five traits and intrinsic success in the new career era: A 15-year longitudinal study on employability and Work-Family conflict. Applied Psychology, 62(1), 124-156. https://doi.org/10.1111/j.1464-0597.2012.00516.x.

Wolff, S.B. (2008). Emotional and social competency inventory: technical manual up-dated ESCI research titles and abstracts, The Hay Group, Boston, MA. https://www.aicte-india.org/

Zhao, Y. (2018). The changing context of teaching and implications for teacher education. Peabody Journal of Education, 93(3), 295-308.

Zhu, X., \& Liu, J. (2020). Education in and after Covid-19: Immediate responses and long-term visions. Postdigital Science and Education, 2(3), 695-699. 